\title{
SPATIAL DISTRIBUTION OF ROAD ASSETS IN INDIAN TOT AUCTIONS
}

\author{
Ravi Shankar ${ }^{1 *}$, Willie $\operatorname{Tan}^{1}$ \\ ${ }^{1}$ Department of Building, School of Design and Environment, National University of Singapore, \\ Singapore 117566
}

(Received: February 2021 / Revised: March 2021 / Accepted: April 2021)

\begin{abstract}
In March and December 2018, the Indian government auctioned two bundles of roads to monetize its assets using the Toll-Operate-Transfer (TOT) model. This paper focuses on understanding spatial distribution of monetized road assets for TOT I and II. Our hypothesis is that there are likely to be strategic reasons for the spatial distribution. The research design consists of comparative case studies of these two auctions. The data sources include in-depth interviews with bidders, government officials, and analysts as well as documentary analyses of concession agreements, bid documents, and other secondary data. It is found that road assets for TOT I were in "politically friendly" states with better asset quality to make them bankable and encourage private participation in future auctions. The bids were well above the reserve price. For TOT II, the assets were of lower quality and three highways out of eight in the auction bundle were in left-leaning opposition-controlled states. The reserve price was also higher, and unfortunately, the bids were too low, and the contract was not awarded.
\end{abstract}

Keywords: Asset Monetization; Asset Recycling; Auctions; Toll-Operate-Transfer Model

\section{INTRODUCTION}

Infrastructure development is a key driver of economic growth (Munnell, 1992; Queiroz, Haas, \& Cai, 1994). However, India was ranked 70th out of 141 countries in terms of the quality of infrastructure (World Economic Forum, 2019), and 44 out of 167 countries in World Bank's Logistics Performance Index in 2018 (World Bank, 2018). An estimated investment of US $\$ 4.5$ trillion is needed in infrastructure till 2040 to sustain its GDP growth (Economic Survey of India, 2018).

To meet this investment requirement, India needs to spend approximately $7 \%$ to $8 \%$ of its GDP annually. However, during 2014-20, the annual infrastructure investment was only about $4.5 \%$ of GDP (Economic Survey of India, 2020). Consequently, in the early 2000s, the government encouraged the private sector to invest into infrastructure projects by providing guarantees, tax breaks, and viability gap funding. Because of a weak bond market, the government also encouraged participation from private, state and shadow banks, which have contributed to approximately $80 \%$ of the total debt in infrastructure projects (Reserve Bank of India, 2020).

From 2002 to 2010, private sector investment in infrastructure grew annually at a rate of $70 \%$ but declined rapidly thereafter (World Bank, 2020). The decline is mainly attributed to problems such as land acquisition, contractual issues, poor governance, and delays in securing licenses, permits, and environment approvals.

*Corresponding author's email: ravishankar@u.nus.edu, Tel.+ 65-83797937

DOI: https://doi.org/10.32783/csid-jid.v4i1.213 
Consequently, banks have become averse to lending in infrastructure projects (Bloomberg, 2018), and developers have also become wary of investing into greenfield PPP projects.

In response, the Indian Government has taken some initiatives such as developing the bond market and setting up infrastructure debt funds (IDFs), infrastructure investment trusts (InvIT), development finance institution (DFI), and National Investment and Infrastructure Fund (NIIF). It also provided financial support to revitalize the PPP model and improve the risk allocation. These initiatives have not proven adequate to revitalize investments into infrastructure sector. The debt markets also failed to take off as most of the infrastructure projects carry noninvestment grade credit rating (Kumari \& Kumar Sharma, 2017; Singh \& Kathuria, 2016).

Arising from these setbacks, the Indian Government has recently experimented with long-term leasing of operational toll roads to the private sector based on the Toll-Operate-Transfer (TOT) model. If successful, this model will be extended to other types of infrastructure projects. The government has identified that US $\$ 40$ billion can be unlocked through asset monetization by FY25 (Economictimes, 2021).

Under the TOT model, the National Highway Authority of India (NHAI) will auction its operational highways and collect funds upfront from winning bidders. The winning bidder has the right to collect toll revenues for 30 years. As the collected funds will be reinvested in new infrastructure projects, the success of TOT model is crucial for NHAI. Because of the government's fiscal constraints, NHAI currently obtains less than $10 \%$ of its annual funding needs through budget allocation (MoRTH Annual Report, 2020).

The TOT procurement route has attracted diverse investors because of the absence of construction risk. These investors include infrastructure funds, insurance companies, pension funds, sovereign wealth funds, O\&M agencies, and tolling agencies. Infrastructure as an asset class provides stable long-term returns that are not correlated with other asset classes. This paper investigates the rationale for the spatial distribution of toll road assets that were monetized during the first and second auctions in 2018. In particular, we seek to uncover if there are strategic reasons for the spatial choice of road assets.

The paper is organized as follows. Section 2 reviews the literature and develops our hypothesis on the spatial choice of road assets for the two auctions. Section 3 provides the research methodology, followed by the data analysis. The final section concludes the paper.

\section{FACTORS AFFECTING THE SPATIAL DISTRIBUTION OF TOLL ROADS}

\subsection{Asset quality}

For each bundle of road assets, quality depends on road capacity and condition, mix of assets, proximity to each other, connectivity with surrounding infrastructure, competing modes of transport, current usage, and regional growth potential. High quality assets tend to reduce revenue risks and attract more bidders. The higher bids will raise government revenues.

In the case of proximity, it is easier to manage road assets that are close to one another to achieve economies of scale, such as in bundling operation and maintenance contracts, procurement of materials, and training of workers. It is difficult to sell poor quality assets even cheaply. The high uncertainty in asset quality results in lower bids because of perceptions of "lemons" (Akerlof, 1970). Markets can also fail in repeat low quality as set sales; that is, it will not attract bidders (Kollock, 1994).

\subsection{Political factors}

In federal democratic states like India, political support from state and local governments is crucial for implementing central government policies. The opposition parties that rule the lower 
levels of government may not support asset monetization if they do not benefit from it. Hence, the central government has several options: it may proceed by central command, incentivize the lower levels of government such as through revenue sharing, or select projects that are not in opposition wards.

Beyond the public sector, the central government may use project auctions to gain support from the private sector by providing opportunities to operate the assets (Khemani, 2012; Kitschelt \& Wilkinson, 2007; Mei \& Moses, 2005). The private sector may also seek "rents" (Krueger, 1974) by influencing the auction structures to their benefit, such as by excluding other bidders through favourable qualifying criteria and providing better contract terms. Finally, politicians and bureaucrats may further their own interests by selecting projects that increase political support or enhance public careers.

\subsection{Social factors}

Although many governments invest in infrastructure to provide greater access for the poor, the bigger challenge is often user affordability. Consequently, the central government is less likely to select projects in poorer regions for lack of revenues and potential resistance. Similarly, it will try to avoid left-leaning southern Indian states where labour unionization is strong (Evans, 2017; Ramaswamy, 1976). Workers in the se regions tend to be suspicious of private enterprise when it comes to delivery of infrastructure because of the profit motive and land acquisition (Ortiz \& Buxbaum, 2008).

\subsection{Strategic factors}

Governments tend to auction their most profitable assets in early sta ges of asset monetization to ascertain private sector interest and attract more bidders in subsequent auctions (Asensio, 2009). They may also use road auctions to promote regional development. If the auctioned roads are well maintained, they will open new markets by improving access and logistics.

Finally, governments may also use road auctions to reform the public sector by introducing competition, new management practices, and private sector efficiencies. In some cases, it is also possible to use privatization to curb union power (Solomon, 2009).

\section{METHODOLOGY}

This study uses a comparative case study design to analyse the spatial distribution of auctioned toll roads. The "comparative" part does so by investigating commonalities and differences between cases, and the "case study" part probes for insights and rationale behind geographical spread of assets. Similar research (Annamalai \& Hari, 2016; Solheim-Kile \& Wald, 2019, 2020; Villani, Greco, \& Phillips, 2017) also used comparative case studies.

The auctions for TOT projects were chosen because they were the first two cases of such auctions in India, and little is known about the rationale behind the spatial distribution of assets in such auctions. Further, the success of TOT auctions is crucial for Indian government due to fiscal constraints. It is unfortunate that the second auction was annulled, resulting in the loss of opportunity to monetize the road assets.

The first and second auctions comprised of nine and eight highway stretches respectively, and each group is bundled as a single bid. Details are given under the "Comparative Case Stud ies" section. The primary data were collected through in-depth interviews with bidders, government officials, and analysts using semi-structured questionnaires. The responses were coded and used to develop themes and a coherent narrative to probe into the rationale behind spatial distribution of assets. The sample includes seven government officials/government consultants, seven analysts (credit rating agencies, financial, technical, and legal ad visors, insurance providers, and 
other industry experts), and four project lenders. Hence the sample is size is eighteen, comprising six officials directly involved in structuring the TOT auctions and twelve industry experts.

The secondary data comprised concession agreements, bid documents, press statements, websites, and scholarly articles. Any confidential information not accessible through primary and secondary data collection were obtained as per "Right to Information" Act of the Government of India (GOI). The data were used for analysing the asset quality, auction design, political, social, and strategic factors that determine the spatial distribution of the toll roads.

\section{COMPARATIVE CASE STUDIES}

\subsection{Background: Highway Financing in India and the Need for Asset Monetization}

The National Highway Authority of India (NHAI) is a government of India's autonomous agency responsible for the development, maintenance, and management of federal highways in India. NHAI's revenues accrue from internal and external sources. The internal sources comprise of toll proceeds, fuel cess, and road tax on new vehicle registrations. The external sources of funds include market borrowings, private investment, and budgetary support. The major expenses include land acquisition, greenfield construction, debt servicing, as well as payments of grants and annuity. A detailed breakdown of the revenue and expenditure of NHAI for FY20 is shown in Figure 1.
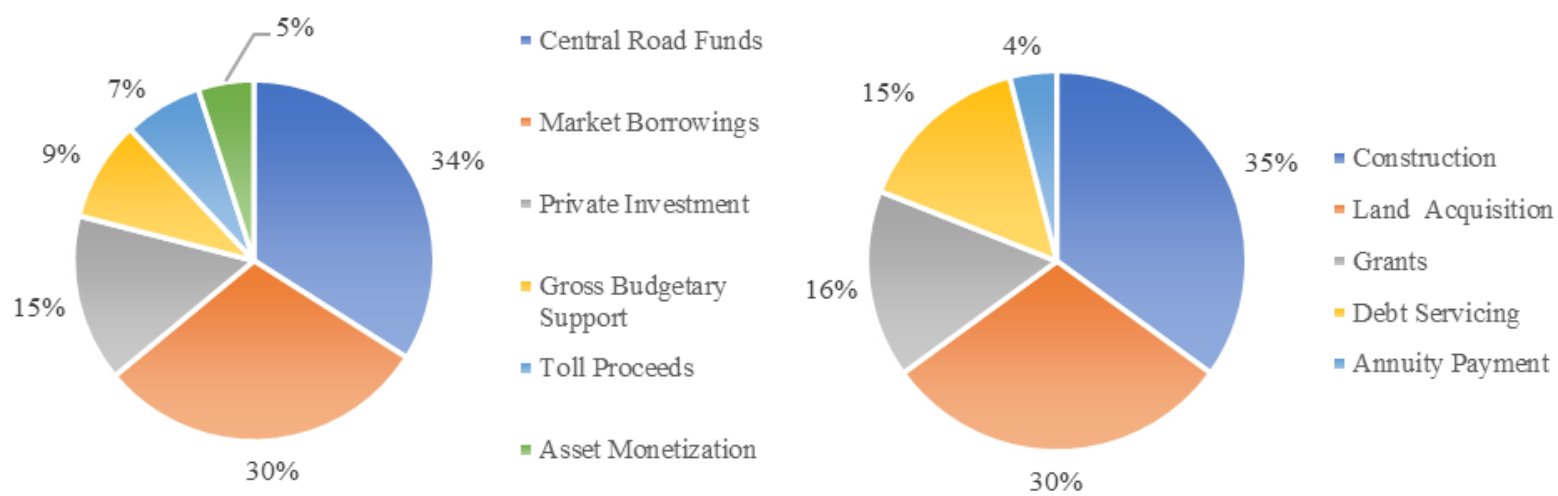

Figure 1 NHAI's sources of funds and expenditure. Source:(MoRTH Annual Report, 2020).

NHAI is heavily reliant on market borrowings and private investment because the internal sources of funds and budgetary support are not sufficient. The market borrowings over last few years have increased drastically because of decline in private investment and increased expenses. The expenses such as grants and annuities rose during Modi government's first term because of the decline in private investment and the consequent need for government support to improve bankability. Further, land acquisition costs have increased 4.5 times from 2014 to 2018 due to the implementation of new Land Acquisition Act of 2014. Finally, increased borrowings have led to a spike in debt servicing expenses (MoRTH Annual Report, 2020).

Faced with these constraints, the GOI plans to generate funds by monetizing its operational assets. It has estimated that US $\$ 40$ billion can be unlocked by FY 25 through monetization of its highways with proven toll collection record (Economictimes, 2021).

\subsection{Experiment with Toll-Operate-Transfer (TOT) Model for Asset Monetization}

NHAI introduced the Toll-Operate-Transfer (TOT) model in 2018 where it will auction its operational highways and collect funds upfront from the winning bidders. The winning bidder 
will get the right to operate the roads and collect toll revenues for a period of 30 years. The government will reinvest the collected funds in new infrastructure projects. The auction requires the approval of cabinet committee on economic affairs (Figure 2).

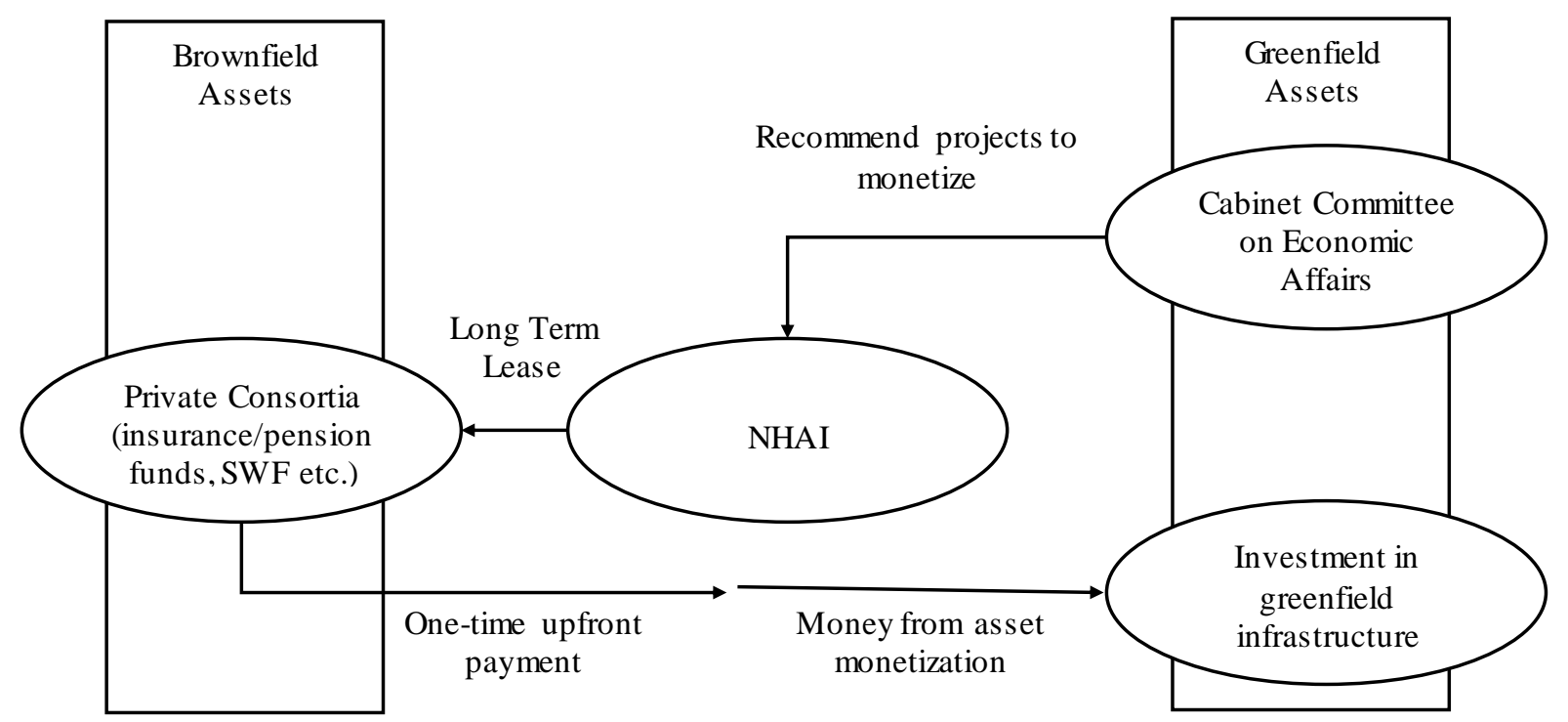

Figure 2 TOT model for infrastructure development in India. Source: (MoRTH, 2016)

The TOT procurement has attracted many investors because of the absence of construction risk. The investors include infrastructure funds, insurance companies, pension funds, sovereign wealth funds, O \& M agencies, and tolling agencies (CRISIL, 2019).

\subsection{Spatial Distribution of Toll Roads in TOT Auctions}

The spatial characteristics of the assets in TOT I (first auction) and TOT II (second auction) are given in Table 1.

Table 1 Characteristics of the assets in both auctions. Source: Tender documents by NHAI.

\begin{tabular}{lll}
\hline Characteristics & TOT I & TOT II \\
\hline Total length (km) & 681 & 587 \\
Number of highways stretches & 9 & 8 \\
States where the toll roads are located & $\begin{array}{l}\text { Gujarat and Andhra } \\
\text { Pradesh }\end{array}$ & $\begin{array}{l}\text { Gujarat, Rajasthan, Bihar, } \\
\text { and West Bengal }\end{array}$ \\
Passenger car unit (PCU)/km & 512 & 251 \\
Expected growth rate in traffic & $10 \%$ & $8 \%$ \\
Expected maintenance cost per km (US\$m) & 0.18 & 0.14 \\
\hline
\end{tabular}

\subsubsection{Asset quality}

The highways in TOT I states are well connected to economic corridors, ind ustrial clusters, consumption centres, and ports. The quality of existing infrastructure in all Indian states is highlighted in form of color-coding in Figure 3 based on the good governance index for year 2019 by National Institution for Transforming India. The darker the state in Figure 3, better is the quality of existing infrastructure, utilities, and regional connectivity. Six out of nine auctioned highways are part of the Golden Quadrilateral connecting four major Indian cities, namely, Delhi, Mumbai, Chennai, and Kolkata. These highway stretches are also close to each other, making it easier to manage and share resources. 
The highways in TOT II are in states with lower economic growth potential and per capita income (CRISIL, 2019). These highway stretches are dispersed with no spatial synergy across assets other than portfolio diversification.
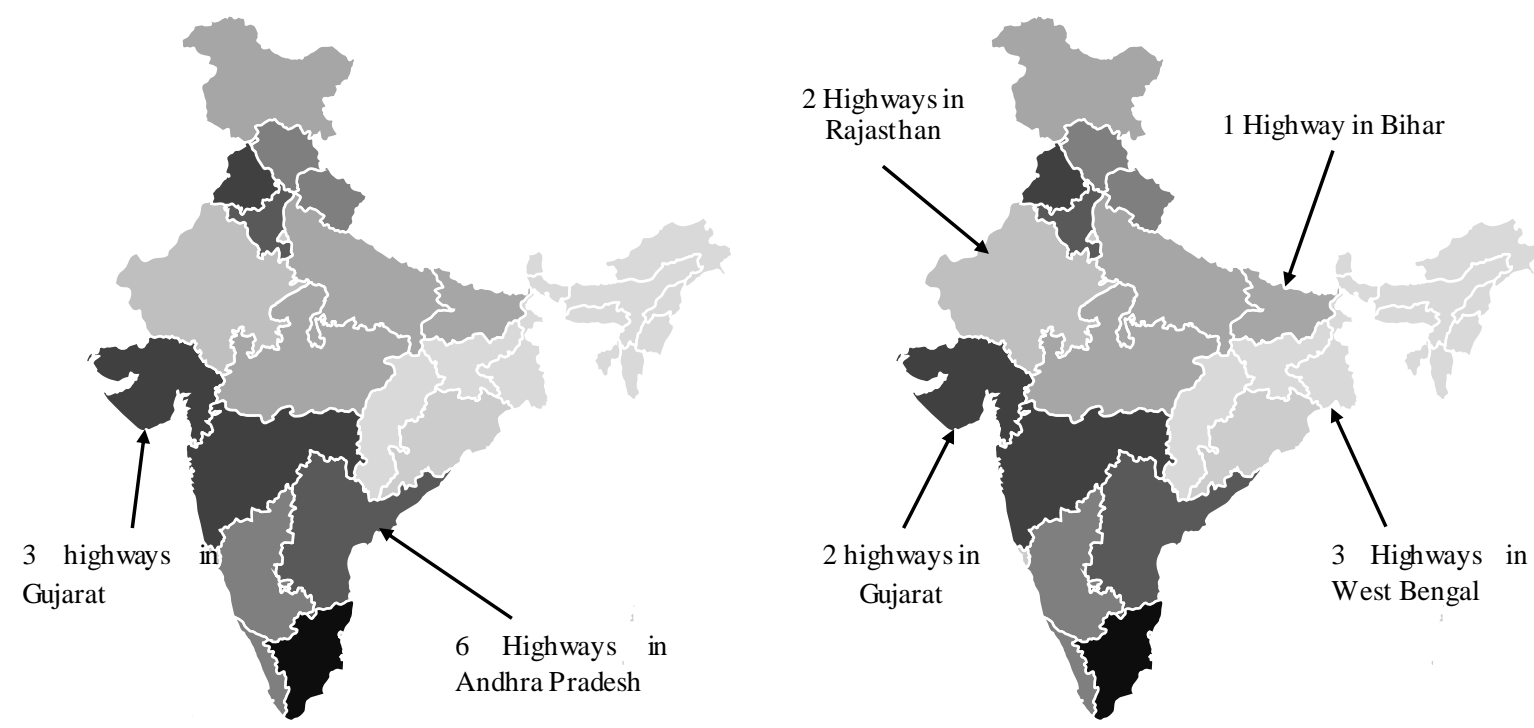

Figure 3 Geographical Spread of Highways in TOT I (left) and TOT II (right).

\subsubsection{Political factors}

The ruling Modi government from the right-winged Bhartiya Janata Party (BJP) also governs the TOT I states. Gujarat is ruled by BJP and Andhra Pradesh is ruled by a BJP ally. However, in case of TOT II, the three highways in West Bengal are in left-leaning opposition territory. The TOT I states have historically exhibited low levels of political competition and electoral volatility as compared to the TOT II, as seen from the average tenure of Chief Ministers (Figure 4). The TOT I states are also better governed (Figure 4), based on the Public Affairs Index 2020 which ranked all the Indian states on metrics such as growth, equity, and compliance with sustainable development goals (Gollerkeri, 2020). Further, TOT I poses fewer political risks as compared to TOT II because only two states are involved, instead of four in TOT II.
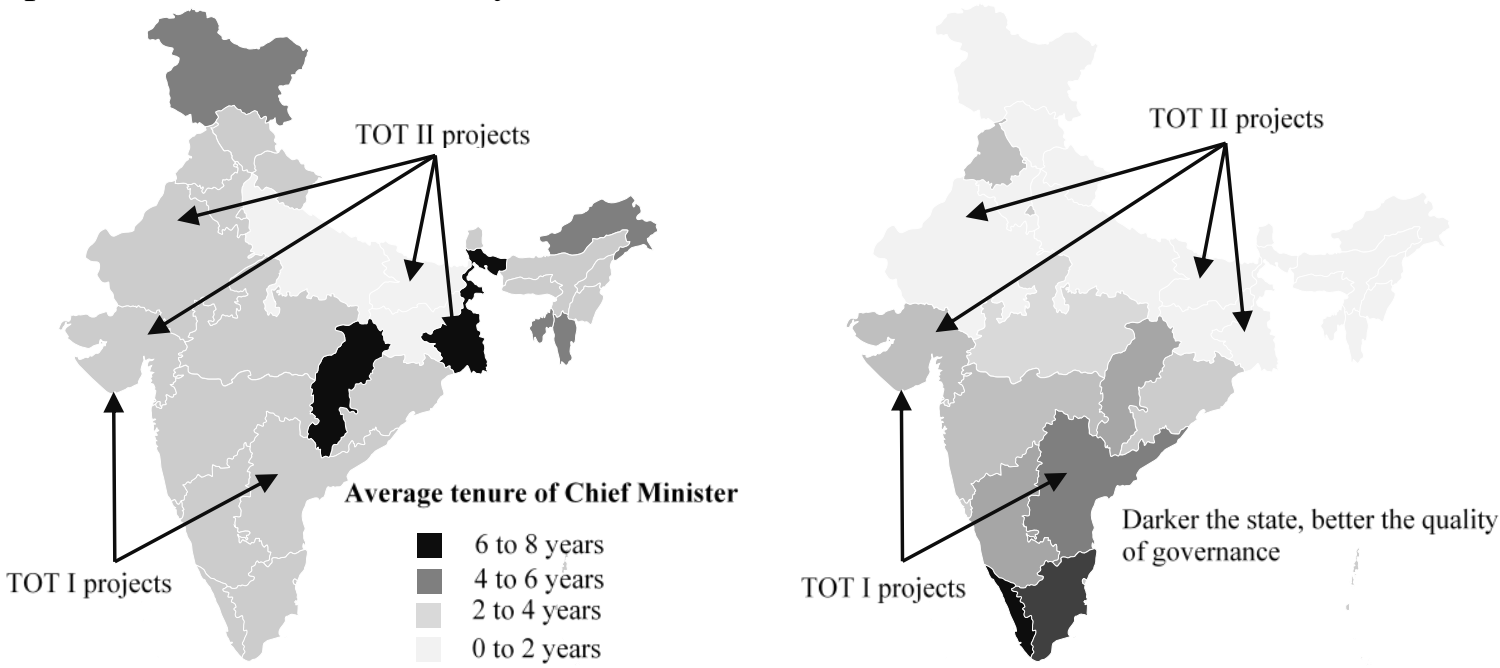

Figure 4 Difference in political stability and governance in states. Source: (Gollerkeri, 2020) 
There is no evidence that the NHAI selects TOT projects to favour certain private investors. It is a puzzle why the opposition-controlled state of West Bengal was selected in TOT II. It may be an experiment to test the ground sentiment in opposition states.

\subsubsection{Social factors}

TOT I states have better user affordability as compared to the TOT II states because of higher per capita income. Consequently, the revenue collected per $\mathrm{km}$ from the tolled roads were higher for TOT I states as compared to TOT II states (Ministry of Road Transport \& Highways, 2018). TOT II projects are also more susceptible to public resistance as compared to TOT I due to the presence of strong labour unions and history of left-leaning politics in TOT II states.

\subsubsection{Strategic factors}

The GOI auctioned its most profitable assets in TOT I to ascertain private sector interest and attract more bidders in subsequent auctions (CRISIL, 2019).

To this end, the government excluded competing routes in the bid documents and chose assets in the least corrupt and most business-friendly states. Based on the India corruption survey carried out by Transparency International India in 2019, TOT I states were ranked among the least corrupt states whereas TOT II states were among the most corrupt states in India. The World Bank also ranked TOT I states higher than TOT II for ease of doing business (Figure 5).
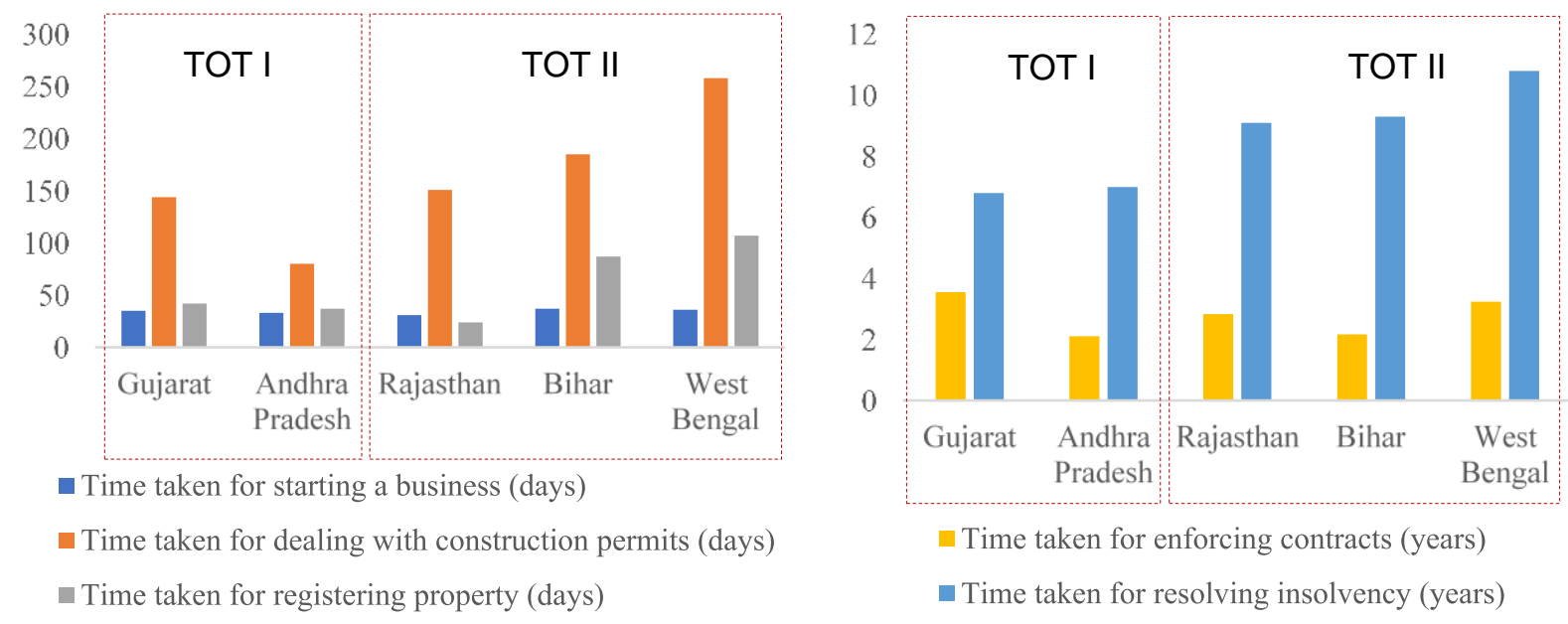

Figure 5 Ease of doing business in the states of TOT I and TOT II. Source: (World Bank, 2019)

To attract foreign investors who can commit large upfront payment to reduce the fiscal stress of NHAI, the government decided to bundle large sections of highways across various states with proven record of toll history. The financial closure was achieved for TOT I in August 2018 and the government plans to reinvest the auction proceeds for regional development.

\subsection{Responses to TOT I and II Auctions}

The response to TOT I auctions was better than expected because the winning bid of INR 9282 crores (US\$1.38 billion at the prevailing exchange rate) by the Macquarie group was well above the reserve price of INR 6258 Crores (US\$0.89 billion at the prevailing exchange rates). There were four bids from different consortiums, each comprising a mix of local and international investors (Figure 6)

There were three bids for TOT II. The bidders were similar to that of TOT I (Figure 6). Unfortunately, bids for TOT II auction were well below the reserve price of INR 5362 Crores 
(US $\$ 0.77$ billion at the prevailing exchange rates), and the contract was not awarded. All bids in TOT I were above the reserve price, whereas in TOT II, all bids were below the reserve price. Also, greater number of companies attended pre-bid meetings before TOT I auction as compared to TOT II.
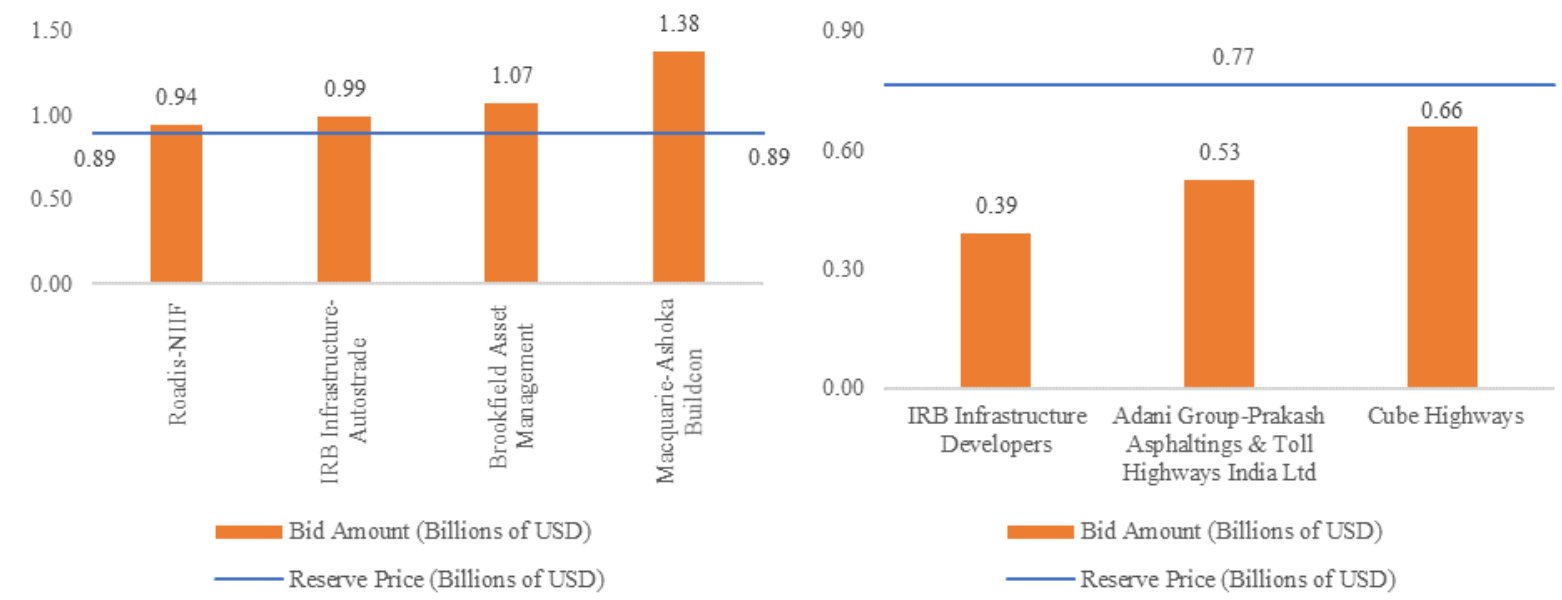

Figure 6 Auction results for TOT I (left) and TOT II (right). Source: (NHAI, 2019).

A diverse set of bidders participated in both the auctions. Such bidders included infrastructure funds, insurance companies, pension funds, sovereign wealth funds, $\mathrm{O} \& \mathrm{M}$ agencies, and tolling agencies (Figure 6). The heterogeneity amongst the bidders in terms of different core competencies, business models, and bidding objectives may have contributed to the spread in bids as observed in both the auctions (Figure 6).

\section{DISCUSSION}

The low bids in TOT reflect the lower asset quality. However, if the profit rate remains the same in the two auctions, lower asset quality and per capita income are not barriers to profitability. Hence, the lower bids may reflect a higher reserve price because of the high bids in TOT I or perceptions of higher risks in TOT II. The higher risks may be due to different economic conditions at time of bid, road assets are in opposition states, differing tender information quality, different bidding objectives, and the presence strong labour unions. A summary of the two auctions is given in Table 2 .

From our interviews, we discovered that the government authorities set higher reserve price to avoid public scrutiny and allegations of selling the family silver to friendly business houses cheaply. The officials cited the coal and 2G spectrum auctions during the second term of Manmohan Singh's government when several cabinet ministers and bureaucrats were prosecuted based on allegations of selling public assets cheaply. The auction outcome of TOT I further influenced NHAI's decision to set up high reserve price for TOT II as the winning bid in TOT I was $55 \%$ more than the reserve price.

The interviewees also indicated that India faced a liquidity squeeze after the bankruptcy of a specialized financial institution, the Infrastructure Leasing \& Financial Services (IL\&FS) in September 2018. It led to the financial crisis in shadow banking sector. Consequently, the cost and availability of funds for the bidders were not same in TOT I and TOT II, because the financial crisis occurred during the period between the two auctions. However, when NHAI revealed the computation of the reserve price to potential bidders, it did not factor in the rising cost of funds and credit rationing. 
Table 2 Summary of the two auctions.

\begin{tabular}{lll}
\hline \multicolumn{1}{c}{ TOT I } & \multicolumn{1}{c}{ TOT II } \\
\hline Asset quality & $\begin{array}{l}\text { Higher traffic density, better road } \\
\text { quality, and proximity of assets. }\end{array}$ & $\begin{array}{l}\text { Lower traffic density, lower road } \\
\text { quality, dispersed assets }\end{array}$ \\
Political factors & $\begin{array}{l}\text { The ruling BJP party controls both the } \\
\text { central and state governments where } \\
\text { roads were auctioned. }\end{array}$ & $\begin{array}{l}\text { were located in the left-leaning } \\
\text { state of West Bengal. }\end{array}$ \\
Social factors & $\begin{array}{l}\text { States with higher per capita income. } \\
\text { Strategic factors }\end{array}$ & $\begin{array}{l}\text { Poorer states with strong labour } \\
\text { unions. }\end{array}$ \\
& $\begin{array}{l}\text { Auctioned the most profitable assets to } \\
\text { attract more bidders in subsequent } \\
\text { auctions. }\end{array}$ & $\begin{array}{l}\text { Auctioned lower quality of assets } \\
\text { in view of high bids in TOT I. }\end{array}$ \\
High bids & Low bids \\
\hline
\end{tabular}

\section{CONCLUSIONS}

This paper examined the factors that affect the spatial distribution of the toll roads in auctions for long-term leasing of Indian toll roads using the Toll-Operate-Transfer (TOT) model. In TOT I, NHAI selected the most profitable routes in government-controlled states to ensure its initial success as a strong signal for subsequent auctions.

In TOT II, NHAI experimented with lower quality routes and three out of eight highways were in left-leaning opposition-controlled states. The bids were below the reserve price. We interviewed diverse stakeholders and found out that the bidders perceived that the reserve price was set too high and projects were too risky during TOT II because of different economic conditions at time of bid, road assets are in opposition states, differing tender information quality, different bidding objectives, and the presence strong labour unions.

These findings highlight the importance of political considerations and experimentation in selecting auction assets. It appears that auctions in government-controlled states tend to produce more favourable outcomes, based on the first two TOT auctions to date. We intend to study future TOT auctions planned over the next few years (MoRTH Annual Report, 2020) to better understand the choice of assets and draw more general conclusions.

\section{REFERENCES}

Akerlof, G. A. (1970). The Market for "Lemons": Quality Uncertainty and the Market Mechanism. The Quarterly journal of economics, 84(3), 488-500. doi:10.2307/1879431

Annamalai, T. R., \& Hari, S. (2016). Innovative financial intermediation and long term capital pools for infrastructure: A case study of infrastructure debt funds. Journal of financial management of property and construction, 21(3), 231-252. doi:10.1108/JFMPC-07-20150024

Asensio, A. M. (2009). A duration model analysis of privatization of municipal water services. Revista de economía aplicada, 17(50), 47. 
Bloomberg. (2018). This Indian Minister Can't Get Bankers to Lend for Road Projects. Retrie ved from https://www.bloomberg.com/news/articles/2018-09-18/risk-averse-bankersshying-away-from-ind ia-road-investments

CRISIL. (2019). Future of TOT. Retrieved from Mumbai, India: https://www.crisil.com/content/dam/crisil/events-tiles/infra-intelligence/2019/future-oftot/future-of-tot.pdf

Economic Survey of India. (2018). India needs \$ 4.5 trillion by 2040 to develop Infra. Retrieved from New Delhi, India: https://www.indiabudget.gov.in/budget20172018/survey.asp

Economic Survey of India. (2020). Retrieved from New Delhi, India: https://www.ind iabudget.gov.in/bud get2020-21/economicsurvey/index.php

Economictimes. (2021). NHAI plans to monetise projects worth Rs 3 lakh crore. Retrieved from https://economictimes.indiatimes.com/industry/services/property-/-cstruction/nhaiplans-to-monetise-projects-worth-rs-3-lakh-crore/articleshow/80957962.cms? from $=\mathrm{mdr}$

Evans, A. (2017). Patriarchal unions = weaker unions? Industrial relations in the Asian garment industry. Third world quarterly, 38(7), 1619-1638. doi:10.1080/01436597.2017.1294981

Gollerkeri, G. S., A; Pandey, S; Kabbur, M; Venkatesh, A. (2020). Public Affairs Index (2020): Governance in the States of India. Retrieved from Bangalore, India: https://pacindia.org/wp-content/uploads/2020/10/pai2020sr.pdf

Khemani, S. (2012). Political Economy of Infrastructure Spending in India. In C. e. Ghate (Ed.), (pp. 526-550).

Kitschelt, H., \& Wilkinson, S. (2007). Patrons, clients, and policies: patterns of democratic accountability and political competition. Cambridge: Cambridge University Press.

Kollock, P. (1994). The emergence of exchange structures: An experimental study of uncertainty, commitment, and trust. American Journal of sociology, 100(2), 313-345.

Krueger, A. O. (1974). The Political Economy of the Rent-Seeking Society. The American economic review, 64(3), 291-303.

Kumari, A., \& Kumar Sharma, A. (2017). Infrastructure financing and development: A bibliometric review. International journal of critical infrastructure protection, 16, 49-65. doi:10.1016/j.ijcip.2016.11.005

Mei, J., \& Moses, M. (2005). Vested Interest and Biased Price Estimates: Evidence from an Auction Market. The Journal of finance (New York), 60(5), 2409-2435. doi:10.1111/j.15406261.2005.00803.x

Ministry of Road Transport \& Highways. (2018). Toll Collection on National Highways on the Rise. Retrieved from New Delhi, India: https://pib.gov.in/Pressreleaseshare.aspx?PRID=1539341

MoRTH. (2016). Ministry of Road Transport and Highways: Standard tender documents for TOT Model. Retrieved from https://morth.nic.in/standard-document

MoRTH Annual Report. (2020). Annual Report of the Ministry of Road Transport and Highways. Retrieved from New Delhi, India: https://morth.nic.in/sites/default/files/Ministry\%20Annual\%20Report_2019-20.pdf

Munnell, A. H. (1992). Policy Watch: Infrastructure Investment and Economic Growth. The Journal of economic perspectives, 6(4), 189-198. doi:10.1257/jep.6.4.189

Ortiz, I. N., \& Buxbaum, J. N. (2008). Protecting the Public Interest in Long-Term Concession Agreements for Transportation Infrastructure. Public works management \& policy, 13(2), 126-137. doi:10.1177/1087724X08326175

Queiroz, C., Haas, R., \& Cai, Y. (1994). National economic development and prosperity related to paved road infrastructure. (1455).

Ramaswamy, E. A. (1976). Trade Unionism and Caste in South India. Modern Asian studies, 10(3), 361-373. doi:10.1017/S0026749X00013020 
Reserve Bank of India. (2020). Annual Report. Retrieved from New Delhi, India: https://www.rbi.org.in/Scripts/Publications.aspx

Singh, P., \& Kathuria, R. (2016). Infrastructure and Connectivity in India: Getting the Basics Right: Infrastructure and Connectivity in India. Asian economic policy review, 11(2), 266285. doi:10.1111/aepr.12144

Solheim-Kile, E., \& Wald, A. (2019). Extending the Transactional View on Public-Private Partnership Projects: Role of Relational and Motivational Aspects in Goal Alignment. Journal of construction engineering and management, 145(5), 4019030. doi:10.1061/(ASCE)CO.1943-7862.0001643

Solheim-Kile, E., \& Wald, A. (2020). Public-private joint ventures in the healthcare sector: enlarging the shadow of the future through social and economic incentives. The International journal of public sector management, 33(6/7), 647-662. doi:10.1108/IJPSM12-2019-0318

Solomon, L. (2009). The Promise and Perils of Infrastructure Privatization: The Macquarie Model (1st 2009. ed.). New York: Palgrave Macmillan US.

Villani, E., Greco, L., \& Phillips, N. (2017). Understanding Value Creation in Public-Private Partnerships: A Comparative Case Study. Journal of management studies, 54(6), 876-905. doi:10.1111/joms.12270

World Bank. (2018). Logistics Performance Index Retrieved from Washington, D.C., United States: https//lpi. worldbank.org/international/global

World Bank. (2019). Ease of doing business in India. Retrieved from Washington, D.C., United States: https $/ /$ www.doingbusiness.org/en/data/exploreeconomies/india

World Bank. (2020). Private Participation in Infrastructure Database Retrieved from Washington, D.C., United States: https://ppi.worldbank.org/en/ppi

World Economic Forum. (2019). The Global Competitiveness Report. Retrieved from Cologny, Switzerland:

http://www3.weforum.org/docs/WEF_TheGlobalCompetitivenessReport2019.pdf 